\title{
Benzo[a]Pyrene Induced p53-Mediated Cell Cycle Arrest, DNA Repair, and Apoptosis Pathways in Chinese Rare Minnow (Gobiocypris Rarus)
}

\author{
Lilai Yuan, ${ }^{1}$ Biping Lv, ${ }^{1}$ Jinmiao Zha, ${ }^{1,2}$ Zijian Wang ${ }^{2,3}$ \\ ${ }^{1}$ Key Laboratory of Drinking Water Science and Technology, Research Center for \\ Eco-Environmental Sciences, Chinese Academy of Sciences, Beijing 100085, China \\ ${ }^{2}$ Beijing Key Laboratory of Industrial Wastewater Treatment and Reuse, Research Center for \\ Eco-Environmental Sciences, Chinese Academy of Sciences, Beijing 100085, China \\ ${ }^{3}$ State Key Laboratory of Environmental Aquatic Chemistry, Research Center for \\ Eco-Environmental Sciences, Chinese Academy of Sciences, Beijing 100085, China
}

Received 7 December 2015; revised 16 May 2016; accepted 21 May 2016

\begin{abstract}
The p53 pathways play an important role in carcinogenesis. In mammals, p53 and p53 target genes have been extensively studied, but little is known about their functions and regulation in fish. In this study, the cDNA fragments of p53 network genes, including $p 53, p 21, m d m 2$, gadd $45 \alpha$, gadd45 $\beta$, igfbp-3, and bax, were cloned from Chinese rare minnow (Gobiocypris rarus). These genes displayed high amino acid sequence identities with their zebrafish orthologs. The mRNA levels of p53 network genes and pathological changes in the liver were determined after adult rare minnow were exposed to $0.4,2$, and $10 \mu \mathrm{g} / \mathrm{L}$ of benzo[a]pyrene $(\mathrm{BaP})$ for 28 days. The results showed that $p 53, p 21, \mathrm{mdm} 2$, gadd $45 \alpha$, and bax mRNA expressions in the livers from males and females were significantly upregulated compared with those of the controls $(p<0.05)$, but gadd $45 \beta$ and igfbp-3 expression was not significantly changed. Microphotographs revealed enlargement of the cell nuclei and cellular degeneration in males, while atrophy and vacuolization of hepatocytes were observed in females $(10 \mu \mathrm{g} / \mathrm{L})$. These results suggested that BaP induced liver DNA repair and apoptosis pathways and caused adverse pathological changes in rare minnow. The strongly responsive p53 network genes in the livers suggest that rare minnow is suitable as an experimental fish to screen environmental carcinogens. In addition, the p53 network genes in rare minnow could feasibly be used to identify the mechanism of environmental carcinogenesis. (c) 2016 Wiley Periodicals, Inc. Environ Toxicol 32: 979-988, 2017.
\end{abstract}

Keywords: benzo[a]pyrene; rare minnow (Gobiocypris rarus); p53 network genes; gene expression; histopathology

Correspondence to: J. Zha; e-mail: jmzha@rcees.ac.cn

Additional Supporting Information may be found in the online version of this article.

Contract grant sponsor: The Key Program of the National Natural Science Foundation of China.

Contract grant number: 21437006.

Contract grant sponsor: The Major International Joint Research Project of the National Natural Science Foundation of China.

Contract grant number: 51420105012 .

Contract grant sponsor: the Water Pollution Control and Treatment of the National Science and Technology Major Project.

Contract grant number: 2014zx-07204-008-003.

Published online 20 June 2016 in Wiley Online Library (wileyonlinelibrary.com). DOI: 10.1002/tox.22298 


\section{INTRODUCTION}

More than $50 \%$ of all human cancers have been shown to contain mutations in the $p 53$ gene (Olivier et al., 2010). p53 is a tumor suppressor protein that has a key role in regulating the cell cycle, apoptosis, and DNA repair (Ananiev et al., 2011). In addition, recent studies have revealed that $\mathrm{p} 53$ has a role in a wide range of biological processes, including aging and longevity, metabolic processes (Gottlieb and Vousden, 2010), autophagy (Vousden and Prives, 2009), reprogramming of stem cells (Zhao and $\mathrm{Xu}, 2010$ ), and the insulin-like growth factor (IGF) and mTOR pathways (Feng et al., 2005). p53 predominantly functions as a transcription factor that can bind to specific DNA sequences, activate downstream gene expression, and trigger cell cycle arrest, DNA repair, and apoptosis (Vousden and Prives, 2009). In mammals, a number of p53 target genes were identified, and the functions of these genes have been studied, for example, p21 (cyclin-dependent kinase inhibitor 1), $c d c 25 c$, and gadd45 (growth arrest and DNA damage-inducible genes), which can initiate cell cycle arrest and DNA repair, and bax (BCL2-associated X protein), puma, noxa, and apaf-1, which promote apoptosis of cells (Shu et al., 2007; Beckerman and Prives, 2010). Moreover, recent studies have shown that p53 activates transcription of microRNAs, which can trigger apoptosis and induce cellular senescence (Hermeking, 2007; Raver-Shapira et al., 2007).

In mammals, p53 and p53 target genes have been extensively studied, but little is known about their functions and regulation in lower vertebrates, including fish (Liu et al., 2011; Mai et al., 2012). p53 homologs have been identified and studied in a number of fish species, such as tilapia (Oreochromis niloticus; Mai et al., 2012), whitefish (Coregonus lavaretus; Brzuzan et al., 2009), zebrafish (Danio rerio; Lee et al., 2007), medaka (Oryzias latipes; Krause et al., 1997), rainbow trout (Oncorhynchus mykiss; Liu et al., 2011), and channel catfish (Ictalurus punctatus; Luft et al., 1998). Fish p53 is highly similar to mammalian p53 in both structure and function (Krumschnabel and Podrabsky, 2009; Storer and Zon, 2010), and many proteins involved in the regulation of p53 levels and stability as well as transcriptional targets of p53 are well-conserved between mammals and fish (Krumschnabel and Podrabsky, 2009). Similar to mammals, p53 is also required for transcriptional activation of a number of p53 target genes in fish, including p21, bax, and $m d m 2$ (mouse double minute 2; Langheinrich et al., 2002; Lee et al., 2007). Nonetheless, functional analyses revealed both similarities and differences between the p53 of mammals and that of several species of fish. For example, genotoxic agents and UV treatment enhanced the expression of p53 in Gulf killifish (Blas-Machado et al., 2000) and Atlantic cod (Gadus morhua; Lesser et al., 2001), respectively. However, in several fish species, researchers have detected little or no change in p53 levels in response to stress factors that are known to upregulate mammalian p53 (Chen et al., 2001; Embry et al., 2006). Moreover, p53 deficiency or over-expression of $\mathrm{mdm} 2$ led to a high rate of spontaneous cancers in mice (Donehower et al., 1992; Jones et al., 1998), but no spontaneous tumor formation occurred during early embryonic development of zebrafish (Langheinrich et al., 2002).

A number of studies have shown the effects of p53 network genes in fish exposed to various environmental pollutants. For example, heavy fuel oil significantly upregulated p53 and gadd45 $\alpha$ transcripts in turbot (Ruiz et al., 2012), $\mathrm{BaP}$ and microcystin-LR significantly induced the expression of p53 and p21 mRNA in whitefish (Brzuzan et al., 2005). Most previous studies examined the effects of p53 network genes, including $p 53, p 21$, gadd $45 \alpha$, and $m d m 2$, in zebrafish (Soares et al., 2012) and turbot (Ruiz et al., 2012) exposed to environmental pollutants (e.g., PAHs). However, molecular characterization and the functions of p53 network genes in rare minnow have not been investigated.

Benzo[a]pyrene $(\mathrm{BaP})$ is one of the most studied environmentally relevant PAHs, and its carcinogenic and mutagenic properties have been extensively evaluated. Previous reports have shown that $\mathrm{BaP}$ induced/repressed large numbers of genes, including genes involved in the cell cycle, apoptosis, and DNA repair (Verhofstad et al., 2010; Hamouchene et al., 2011). BaP is most often linked to cancer because it is a well-established chemical mutagen (Thompson et al., 2010). Therefore, BaP is suitable as a reference chemical to study the responses of p53 target genes in fish.

The rare minnow is distributed mostly in the upstream region of the Yangtze River and in the Sichuan province of China, and it is used as an experimental animal for the assessment of environmental pollutants due to its small size, ease of culture, short life cycle, and prolific egg production with high fertilization and hatching rates (Zha et al., 2007; Li et al., 2009). The aim of this study was to identify $p 53$, p21, mdm2, gadd45 $\alpha$, gadd45 $\beta$, igfbp-3 (IGF-binding protein 3), and bax genes in rare minnow and to investigate the effects of $\mathrm{BaP}$ on p53 network genes and histopathological changes in the livers of rare minnow. These data could contribute to our understanding of the mechanism of carcinogenesis induced by environmental pollutants (e.g., BaP).

\section{MATERIALS AND METHODS}

\section{Chemicals and Reagents}

$\mathrm{BaP}(>98 \%$ purity) and acetone were purchased from Sigma (USA). A stock solution of $\mathrm{BaP}$ was prepared by dilution in acetone. A vehicle treatment containing a combination of acetone served as a control. The ratio of vehicle to water was $1: 10,000(\mathrm{v} / \mathrm{v})$. 


\section{Fish Care and Exposure}

The brood stock of rare minnow was raised in a flowthrough system with dechlorinated tap water $(\mathrm{pH} 7.2-7.6$; hardness $44.0-61.0 \mathrm{mg} \mathrm{CaCO}_{3} / \mathrm{L}$; and temperature $25 \pm$ $1^{\circ} \mathrm{C}$ ) and a photoperiod of $16: 8 \mathrm{~h}$ (light:dark) that has been used for testing chemicals in our laboratory for more than 10 years (Zha et al., 2007; Li et al., 2009). Fish were fed a commercial diet (Trea, Germany) at a rate of $0.1 \%$ body weight per day and newly hatched brine shrimp (Artemia nauplii) two times daily.

Healthy five-month-old adult rare minnow $(n=150)$ and the offspring from the same pair of brood stock were randomly divided into five groups. The body weights and lengths were $0.7 \pm 0.21 \mathrm{~g}$ and $48.21 \pm 3.7 \mathrm{~mm}$, respectively. Fish were kept in glass containers $(3 \mathrm{~L})$ in a water bath at $25^{\circ} \mathrm{C}$ and were exposed after two weeks of acclimation. Fish were exposed to $\mathrm{BaP}$ concentrations of $0.4,2$, and $10 \mu \mathrm{g} / \mathrm{L}$, a control group received water, and a solvent control group received $0.01 \%$ acetone in water. The fish were randomly distributed into five experimental groups. Each group contained three replicate aquaria, and each replicate aquarium included 10 fish. The test solution was renewed each day during a 28 day exposure period. During the experiment, the water temperature was maintained at $25 \pm 1^{\circ} \mathrm{C}$ and the $\mathrm{pH}$ at $7.0 \pm 0.2$. Fish were fed twice a day with brine shrimps. After 28 days of exposure, the fish were sacrificed, and the tissues were excised, immediately frozen into liquid nitrogen, and stored at $-80^{\circ} \mathrm{C}$.

\section{Cloning cDNA Fragments of p53 Pathway Genes}

Total RNA was isolated from the livers of rare minnow using the SV Total RNA Isolation System following the manufacturer's protocol (Promega, USA). Then, RNA samples were dissolved in ribonuclease-free water and stored at $-80^{\circ} \mathrm{C}$ for RT-PCR analysis. The quantity and purity of the RNA samples were determined with a spectrophotometer (Thermo Fisher). The $\mathrm{OD}_{260 / 280}$ ratio ranged from 1.8 to 2, and the integrity of the RNA was assessed by visualization of the $28 \mathrm{~S}$ and $18 \mathrm{~S}$ ribosomal RNA bands.

The RT-PCR analysis was carried out as previously described (Li et al., 2009). The reverse transcription reaction mixtures containing $10 \mu \mathrm{L}$ of total RNA, $2 \mu \mathrm{L}(0.05 \mu \mathrm{g} / \mu \mathrm{L})$ of oligo(dT) $)_{15}$ (Promega), and diethylpyrocarbonate-treated water (a total volume of $12 \mu \mathrm{L}$ ) were heated to $70^{\circ} \mathrm{C}$ for 5 min and quickly chilled on ice. After cooling, $50 \mathrm{mM}$ Tris$\mathrm{HCl}$ buffer ( $\mathrm{pH} 8.3$ ), $75 \mathrm{mM} \mathrm{KCl}, 10 \mathrm{mM}$ dithiothreitol, $3 \mathrm{mM} \mathrm{MgCl}_{2}, 2 \mathrm{mM}$ deoxynucleotide triphosphates $(10 \mathrm{mM}$ each), 40 units of RNAsin (RNase inhibitor; Promega), and 200 U of Moloney Murine Leukemia Virus Reverse Transcriptase (Promega) were added for a total volume of $25 \mu \mathrm{L}$ and incubated for $1 \mathrm{~h}$ at $37^{\circ} \mathrm{C}$. Then, the reaction mixture was heated to $70^{\circ} \mathrm{C}$ for $10 \mathrm{~min}$ to stop the reverse transcription.

To obtain cDNA fragments of the p53 pathway genes (p53, p21, mdm2, gadd45 $\alpha$, gadd $45 \beta$, igfbp-3, and bax $)$, the primer pairs were designed based on the highly conserved regions of known sequences from other fish species available in GenBank (Table I). The detailed information of the PCR experiment is as follows: each $50 \mu \mathrm{L}$ DNA amplification reaction contained polymerase chain reaction buffer $(20 \mathrm{mM}$ Tris- $\mathrm{HCl}, \mathrm{pH} 8.4,50 \mathrm{mM} \mathrm{KCl}, 1.5 \mathrm{mM} \mathrm{MgCl}_{2}$ ), $200 \mu \mathrm{mol}$ dNTPs (Promega), 20 pmol of each gene-specific primer, 1 $\mu \mathrm{L}$ of a 20 -fold dilution of total cDNA, and 2.5 U Taq DNA polymerase (Invitrogen). The thermocycler program included a denaturation step at $94^{\circ} \mathrm{C}(8 \mathrm{~min}) ; 35$ cycles of $94^{\circ} \mathrm{C}(30 \mathrm{~s}), 55^{\circ} \mathrm{C}(30 \mathrm{~s})$, and $72^{\circ} \mathrm{C}(30 \mathrm{~s})$; and a final elongation step at $72^{\circ} \mathrm{C}(10 \mathrm{~min})$. The PCR amplification products were analyzed by $1.5 \%$ agarose gel electrophoresis. The bands with the expected sizes were excised and purified using an Agarose Gel DNA Purification Kit Version 2.0 (TaKaRa, Japan). The isolated fragments were cloned into the pMD 19-T vector (TaKaRa, Japan) and transformed into Escherichia coli (DH $5 \alpha$ ). The partial cDNAs were sequenced and compared using BLAST to the sequences available in GenBank, and sequence alignment and phylogenetic analyses were performed with known sequences from other fish species and mammals to confirm the identity of the clones.

\section{Hepatosomatic Indices (HSI) and Histological Analysis}

The gender-specific body weight, liver weight, and body length of the experimental fish were measured. To determine the gender, the fish was dissected, and the gender was identified by observing the gonads of each fish. The HSI were calculated as follows: HSI $=[$ Liver weight $(\mathrm{g}) /$ Fish weight $(\mathrm{g})]$ $\times 100$

Liver samples fixed in Bouin's solution were transferred to $70 \%$ ethanol and processed according to standard histological methods and embedded in paraffin wax as described by Wolf et al. (2004). The sections were cut at 3-4 $\mu \mathrm{m}$, stained with hematoxylin and eosin, and observed on a Axioskop 2 mot plus optical microscope (Zeiss, Germany) and digitized with a AxioCam digital camera (Zeiss, Germany) using the Application Suite software AxioVision Rel. 4.5 (Zeiss, Germany).

\section{Real-Time PCR}

Real-time PCR was performed to determine the expression levels of $p 53, p 21, m d m 2$, gadd $45 \alpha$, gadd $45 \beta$, igfbp -3 , and bax. Real-time PCR was performed using a MX3005P realtime quantitative PCR system (Stratagene) with a total volume of $25 \mu \mathrm{L}$, consisting of the Brilliant II SYBR Green QPCR master mix (Promega), $300 \mathrm{nM}$ forward primer and 
TABLE I. Primer sequences used for cloning of bax, gadd45, igfbp-3, mdm2, p21, and p53, and quantification of p53 pathway genes expression by real-time PCR in rare minnow

\begin{tabular}{|c|c|c|c|}
\hline Gene & Sequence $\left(5^{\prime} \rightarrow 3^{\prime}\right)$ & Product Size (bp) & Genbank Accession No. \\
\hline \multicolumn{4}{|l|}{ Cloning } \\
\hline \multirow[t]{2}{*}{$\operatorname{Bax}$} & F: CTGGGGAAGAGTTGTGGC & 228 & KC477758 \\
\hline & R: GCGAGGAAAACTCCGACT & & \\
\hline \multirow[t]{2}{*}{ gadd $45 \beta$} & F: AAAAGCCAGGTCCATAAAG & 204 & KC477759 \\
\hline & R: GAAACCCTTTTGGTCACAG & & \\
\hline \multirow[t]{2}{*}{$i g f b p-3$} & F: AAAAGCAAAGCGGCAGTC & 454 & KC477760 \\
\hline & R: GAACGATCCAACCGGAAA & & \\
\hline \multirow{2}{*}{$m d m 2$} & F: AGCCTGTCTTGGTGCG & 298 & KC477761 \\
\hline & R: CTCGGTTATCTCAGTATCTTCA & & \\
\hline \multirow[t]{2}{*}{$p 21$} & F: ATCTGGTTGGCGATGAGC & 280 & KC477762 \\
\hline & R: GCCGAAATCAGTGAGTTTGA & & \\
\hline \multirow[t]{2}{*}{ p53 } & F: GCAGGCCCATCCTCACAA & 240 & KC477763 \\
\hline & R: AAGAAGATTCTTTCACCAAA & & \\
\hline \multirow[t]{2}{*}{$\operatorname{gadd} 45 \alpha$} & F: TGTGGAGATAACGCAACG & 232 & KC477764 \\
\hline & R: GGTGAAGTGAATCTGGAG & & \\
\hline \multicolumn{4}{|c|}{ Real-time PCR } \\
\hline \multirow[t]{2}{*}{$\beta$-actin } & F: CAGGGCGTGATGGTGGGGAT & 226 & \\
\hline & R: GGTTGGCTTTGGGGTTGAG & & \\
\hline \multirow[t]{2}{*}{ Bax } & F: ATTTCAACCAGGGTTCCT & 110 & \\
\hline & R: GTCCCATCCACCCTGTTC & & \\
\hline \multirow[t]{2}{*}{$\operatorname{gadd} 45 \beta$} & F: CTGCGTTGTGCTGTGCAT & 127 & \\
\hline & R: GAAACCCTTTTGGTCACAG & & \\
\hline \multirow[t]{2}{*}{$i g f b p-3$} & F: GAAACCCTTTTGGTCACAG & 106 & \\
\hline & R: TCCAGGTATGCGAGGTTG & & \\
\hline \multirow[t]{2}{*}{$m d m 2$} & F: GTCTTCGGACGCACGCAG & 114 & \\
\hline & R: ATGGACTCCACCTCAAACT & & \\
\hline \multirow[t]{2}{*}{$p 21$} & F: TAAGGTACTATGAAGGATGCC & 92 & \\
\hline & R: AGAGGGATTATGGGACAGA & & \\
\hline \multirow[t]{2}{*}{ p53 } & F: CCATCCTCACAATCATCAC & 74 & \\
\hline & R: CTCCTCAGTTTTCCTGTCTC & & \\
\hline \multirow[t]{2}{*}{$\operatorname{gadd} 45 \alpha$} & F: TGTCGTCGGGAGATGGAAT & 139 & \\
\hline & R:GTTGTTCACTCGCAAGAT & & \\
\hline
\end{tabular}

$300 \mathrm{nM}$ reverse primer. The thermal cycle parameters were $10 \mathrm{~min}$ at $95^{\circ} \mathrm{C}, 40$ cycles of $30 \mathrm{~s}$ at $95^{\circ} \mathrm{C}, 1 \mathrm{~min}$ at $57^{\circ} \mathrm{C}$, and $30 \mathrm{~s}$ at $72^{\circ} \mathrm{C}$. All samples were analyzed in triplicate, and the mean value of these triplicate measurements was used to calculate the mRNA expression. The results were analyzed according to the delta-delta $\mathrm{Ct}$ method (Schmittgen and Livak, 2008), and $\beta$-actin was used as the internal control gene. Dissociation curve analysis was performed for each gene to evaluate the amplification of untargeted fragments. The efficiency of the primer sets was assessed with a standard curve via a dilution series, the linear correlation $\left(R^{2}\right)$ between the mean $\mathrm{Ct}$ and the logarithm of the cDNA dilution was $>0.99$ (ranging from 0.991 to 0.998 ) in each case, and the efficiencies ranged from 95.1 to $104.8 \%$.

\section{Statistics}

Statistical analyses were performed with SPSS (version 13.0) and OriginPro (version 8.0). The experimental data were assessed for homogeneity of variance across treatments using Levene's test. All quantitative data are expressed as the mean \pm standard error of the mean (SEM). Statistical analysis of the data was performed using an ANOVA, followed by Duncan's multiple range test. A probability of $p<0.05$ was considered statistically significant.

\section{RESULTS}

\section{Nucleotide and Predicted Amino Acid Sequences Analysis}

The partial cDNA fragments of $p 53, p 21, m d m 2, \operatorname{gadd} 45 \alpha$, gadd $45 \beta$, igfbp-3, and bax were isolated and cloned from rare minnow. Cloned cDNAs were sequenced and compared to sequences in GenBank using BLAST analysis. Phylogenetic analysis revealed that the putative proteins of p53, p21, $\operatorname{mdm} 2$, gadd $45 \alpha$, gadd $45 \beta$, and igfbp- 3 in rare minnow had high amino acid similarities to those of other fish and 
TABLE II. Growth and the HSI of adult fish exposed to BaP for $28 \mathrm{~d}$

\begin{tabular}{|c|c|c|c|c|c|c|}
\hline \multirow{2}{*}{$\begin{array}{l}\text { Concen. } \\
(\mu \mathrm{g} / \mathrm{L})\end{array}$} & \multicolumn{2}{|c|}{ Body weight (g) } & \multicolumn{2}{|c|}{ Body length (mm) } & \multicolumn{2}{|c|}{ HSI (\%) } \\
\hline & Males & Females & Males & Females & Males & Females \\
\hline Control & $0.86 \pm 0.13$ & $1.35 \pm 0.56$ & $44.81 \pm 4.01$ & $52.32 \pm 3.51$ & $2.18 \pm 0.38$ & $2.18 \pm 0.38$ \\
\hline 0.4 & $0.87 \pm 0.22$ & $1.24 \pm 0.37$ & $45.11 \pm 1.61$ & $51.51 \pm 1.11$ & $2.01 \pm 0.39$ & $1.88 \pm 0.45$ \\
\hline 2 & $0.89 \pm 0.24$ & $1.11 \pm 0.31$ & $47.51 \pm 4.11$ & $53.11 \pm 2.61$ & $2.14 \pm 0.54$ & $2.07 \pm 0.44$ \\
\hline 10 & $0.84 \pm 0.19$ & $1.12 \pm 0.23$ & $42.01 \pm 4.31$ & $52.71 \pm 2.91$ & $1.95 \pm 0.37$ & $1.47 \pm 0.42^{\mathrm{a}}$ \\
\hline
\end{tabular}

Data expressed as mean \pm SEM of each treatment (males, $n=15$; females, $n=15$ ).

${ }^{\text {a }}$ Statistically significant difference from the control $(p<0.05)$.

mammalian species, confirming their identities (Supporting Information Fig. S1). The partial cDNA sequences for rare minnow had high similarity with the same regions in zebrafish for $p 53$ (88\%), p21 (85\%), mdm2 (99\%), gadd45 $\alpha$ (99\%), gadd45 $\beta$ (92\%), bax (91\%), and igfbp-3 (90\%). The cloned sequences have been deposited in GenBank, and the accession numbers of $p 53, p 21, m d m 2$, gadd $45 \alpha$, gadd $45 \beta$, bax, and igfbp-3 are KC477763, KC477762, KC477761, KC477764, KC477759, KC477758, and KC477760, respectively.

\section{Growth, HSI, and Histopathology}

The body lengths and body weights of adult rare minnow exposed to $\mathrm{BaP}$ for 28 days were not significantly different compared with those of the controls (Table II). Because no significant difference was observed between the acetone control and water control for the body lengths, body weights and HSI, as well as the gene expression, the water control was used as the control group for subsequent experiments. Compared with the control, BaP caused significant decreases in HSI in females exposed to $\mathrm{BaP}$ at $10 \mu \mathrm{g} / \mathrm{L}(p<0.05$, Table II).

Normal hepatic tissue exhibited a regular hepatocyte structure with evident, well-defined nuclei [Fig. 1(A,C)]. No significant histological changes were found in the liver of males and females exposed to low concentrations of BaP. However, microphotographs revealed enlargement of the cell nuclei and cellular degeneration in male rare minnow treated with high concentrations of $\mathrm{BaP}(10 \mu \mathrm{g} / \mathrm{L})$ [Fig. 1(B)]. Atrophy and vacuolization of the hepatocytes were observed in females at high concentrations $(10 \mu \mathrm{g} / \mathrm{L})$ [Fig. 1(D)].

\section{Quantitation of p53 Pathway Genes}

The mRNA expressions of $p 53, p 21, m d m 2$, gadd $45 \alpha$, gadd $45 \beta$, igfbp-3, and bax in the livers of males and females
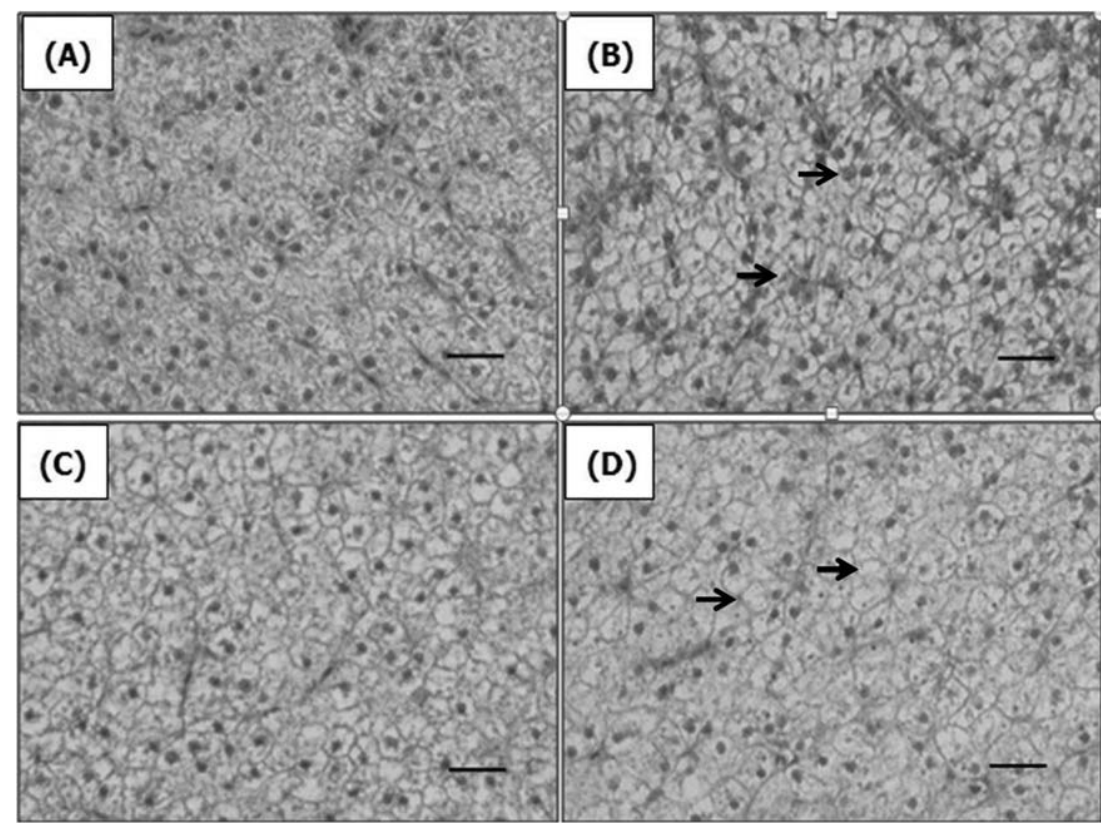

Fig. 1. Microphotographs of the liver from rare minnow (Grobiocypris rarus), stained with hematoxylin and eosin: (A) Liver from male control, (B) Liver from male fish exposed to $10 \mu \mathrm{g} / \mathrm{L} \mathrm{BaP,} \mathrm{(C)} \mathrm{Liver} \mathrm{from} \mathrm{female} \mathrm{control,} \mathrm{(D)} \mathrm{Liver} \mathrm{from} \mathrm{female} \mathrm{fish}$ exposed to $10 \mu \mathrm{g} / \mathrm{L}$ BaP. The black arrows indicated enlargement of the cell nuclei in $\mathrm{B}$, and vacuolization and atrophy of hepatocytes in $\mathrm{C}$. The images shown are representative of three replicate aquaria per treatment, bar $=20 \mu \mathrm{m}$. 


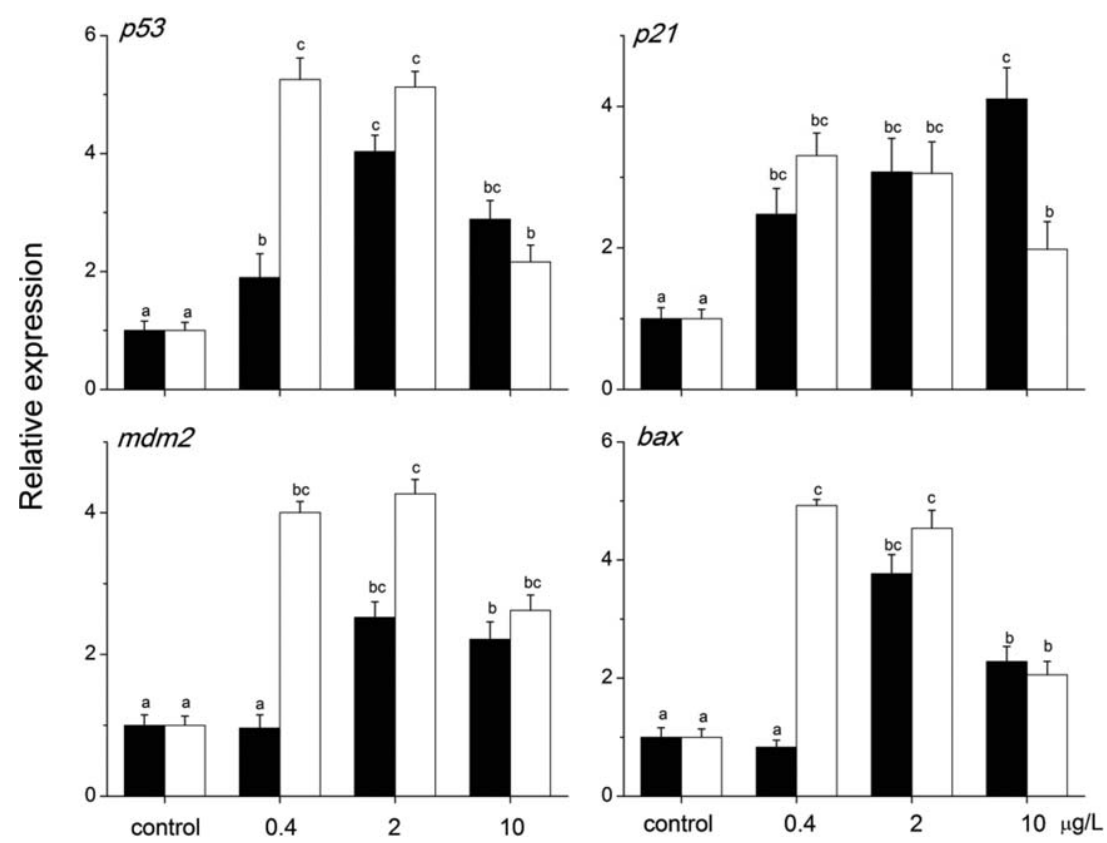

Fig. 2. Expression levels of $p 53, p 21, m d m 2$, and bax mRNA in the livers of adult rare minnow (males $\square$ and females $\square$ ) exposed to BaP for $28 \mathrm{~d}$. Values are presented as the mean \pm SEM. A significant difference between the groups of $p<0.05$ $(n=3-5$, ANOVA) is indicated by differences in the letters above the bars.

were determined after 28 days of exposure to BaP. The liver p53 mRNA expression was significantly upregulated compared with that of the controls at BaP concentrations above $0.4 \mu \mathrm{g} / \mathrm{L}(p<0.05$, Fig. 2). For males, $p 21 \mathrm{mRNA}$ levels in all treatments and $m d m 2$, gadd45 $\alpha$, bax mRNA levels at 2 and $10 \mu \mathrm{g} / \mathrm{L} \mathrm{BaP}$ were significantly induced compared with those of the controls ( $p<0.05$, Figs. 2 and 3). For females, mRNA levels of $p 21, m d m 2$, gadd $45 \alpha$, and bax were significantly induced in all treatments compared with those of the controls ( $p<0.05$, Figs. 2 and 3). In addition, expressions of gadd $45 \beta$ and $i g f b p-3$ in the livers of males and females in all treatment groups were not significantly changed (Fig. 3).

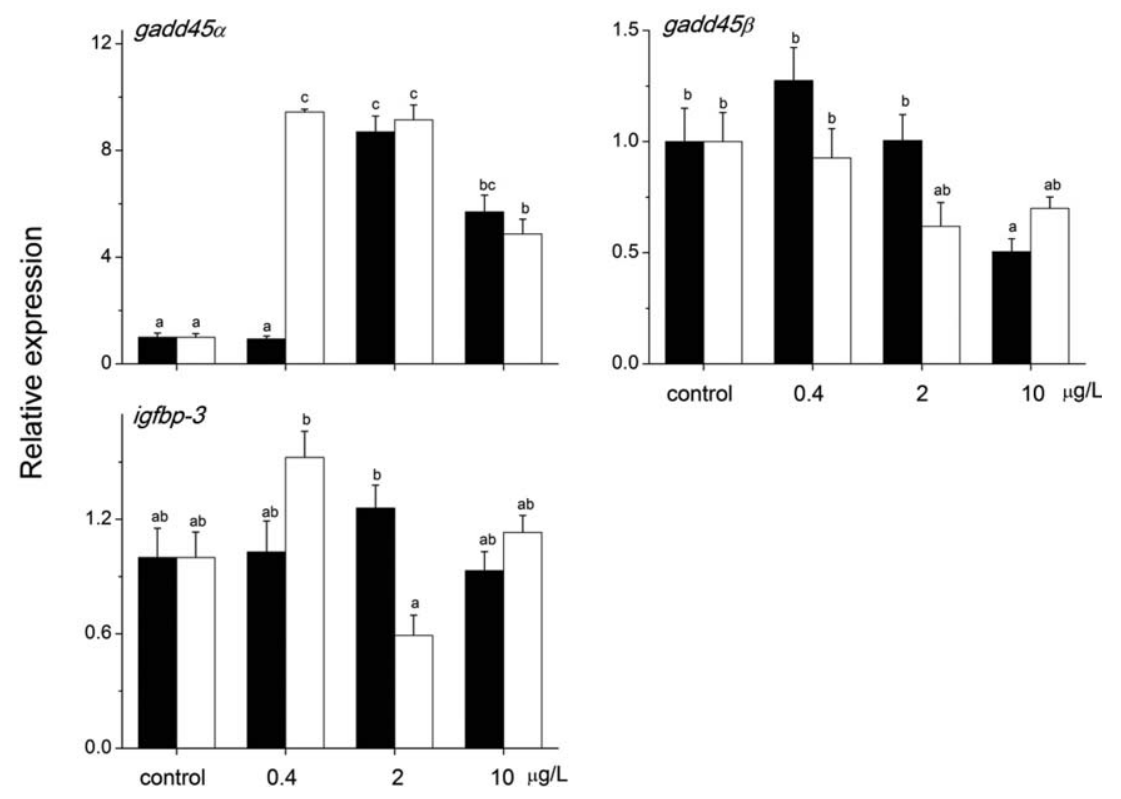

Fig. 3. Expression levels of gadd $45 \alpha$, gadd $45 \beta$, and igfbp-3 mRNA in the livers of after adult rare minnow (males $\mathbf{\square}$ and females $\square$ ) exposed to BaP for $28 \mathrm{~d}$. Values are presented as the mean \pm SEM. A significant difference between the groups of $p<0.05$ ( $n=3-5$, ANOVA) is indicated by differences in the letters above the bars. 


\section{DISCUSSION}

\section{Identification of New p53 Pathway Genes in Rare Minnow}

In our study, seven previously unidentified p53 network genes in rare minnow were cloned and identified. The partial fragments of these p53 network genes were sequenced and submitted to GenBank. Based on the sequence and phylogenetic analysis of their predicted amino acid sequences, the new transcripts were classified as $p 53, p 21, \operatorname{mdm} 2, \operatorname{gad} d 45 \alpha$, gadd $45 \beta$, igfbp-3, and bax. In general, the predicted amino acid sequences of the genes exhibited high homology with the same regions in zebrafish (Soares et al., 2012).

\section{Histopathology}

Histopathological alterations have been assessed in various tissues of fish for decades to determine the effects of environmental contaminants both in field and laboratory settings. In addition, the liver has been the focus of histopathological biomarkers because of its key role in processes such as metabolism of xenobiotics and synthesis of vitellogenin (Dabrowska et al., 2012). There have been numerous reports demonstrating the histopathological alterations in the livers of fish exposed to various environmental pollutions ( $\mathrm{Au}$, 2004).

In this study, significant histopathological changes, including enlargement of the cell nuclei, atrophy and vacuolization of hepatocytes, and decreases in the diameter of hepatocytes, were observed in the livers of rare minnow exposed to $\mathrm{BaP}(10 \mu \mathrm{g} / \mathrm{L})$. Similarly, significantly more hepatic foci in Atlantic killifish exposed to $200 \mu \mathrm{g} / \mathrm{L} \mathrm{BaP}$ for 24 h were observed (Wills et al., 2010). Atrophy and vacuolization of the hepatocytes have been observed in several fish exposed to PAHs, and cytoplasmic vacuolation is usually produced by deposition of glycogen and lipids, which eventually leads to the displacement and deformation of the nucleus (Pal et al., 2011). In addition, hypertrophy of the hepatocytes in males and females was observed in rare minnow exposed to atrazine and 3-amino-1,2,4-triazole at 10 $\mu \mathrm{g} / \mathrm{L}$ (Li et al., 2009; Yang et al., 2010). These results suggest that histopathological alteration is a direct and valid way to identify the effects of environmental carcinogens.

\section{Induction of p53 Pathway Genes}

p53 is a tumor suppressor protein that has a key role in regulating the cell cycle, apoptosis, and DNA repair. The principal mechanisms regulating the activity of p53 at the protein level (Braithwaite et al., 2005) and the increased cellular p53 protein levels following exposure to various genotoxic agents are mainly due to an increase in the stability of the p53 protein rather than an increase in the levels of p53 mRNA (Park et al., 2006). However, several studies have suggested that PAH-stimulated p53 accumulation may also be transcriptionally induced (Pei et al., 1999; Park et al., 2006). Moreover, a number of studies have indicated that genotoxic chemicals could modulate $p 53$ mRNA expression, and it has been suggested as a biomarker (Brzuzan et al., 2005; Brzuzan et al., 2011). In this study, BaP significantly induced the expression of p53 mRNA in rare minnow livers. Similar results were obtained in human cells (Pei et al., 1999) and whitefish (Brzuzan et al., 2005) exposed to BaP, indicating that BaP-induced p53 expression is partly regulated at the transcriptional level (Pei et al., 1999). In contrast, other studies have shown that $\mathrm{BaP}$ and dioxin suppressed the mRNA expression of $p 53$ in rainbow trout (Brzuzan et al., 2011) and human epidermal keratinocytes (Ray and Swanson, 2004), respectively. The authors indicated that the repression of p53 mRNA expression requires the involvement of AhR and is mediated by DNA methylation (Ray and Swanson, 2004). Nonetheless, p53 mRNA could be a potential biomarker to screen environmental carcinogens.

Because p53 has crucial roles in regulating cell survival and death, its expression is tightly regulated at multiple levels (Vilborg et al., 2010) and maintained at low levels under normal conditions. The turnover of p53 is regulated by the p53 target gene $m d m 2$, which is the major negative regulator of p53 levels and activity in mammals (Momand et al., 1992). In this study, a significant increase in $m d m 2$ gene transcription in the males and females was observed. Similarly, statistically significant differences in $m d m 2$ expression levels were observed in laryngeal carcinoma samples (Hassumi-Fukasawa et al., 2012). Our finding that p53 and $m d m 2$ increased upon $\mathrm{BaP}$ exposure could be due to the auto-regulatory feedback loop described in mammals for this complex of proteins (Soares et al., 2012). However, molecular analysis of zebrafish $\mathrm{mdm} 2$ revealed that it seems to lack some key amino acids for DNA binding found in other models (Neel et al., 2000), and the regulation of p53 activity in fish may not be dependent on mdm 2 in the same way or to the same extent as that in mammals (Krumschnabel and Podrabsky, 2009).

The p53 pathway responds to various cellular stress signals by activating p53, which functions as a transcription factor. Figure 4 shows the program that p53 respond to BaP exposure. In the present study, to elucidate the effects of $\mathrm{BaP}$ on p53 signaling pathways, we analyzed the transcriptional levels of several p53 downstream genes (e.g., p21, gadd45a, and bax), which are key players in cell cycle regulation, DNA repair and apoptosis. The cyclin-dependent kinase inhibitor p21 (also known as p21 ${ }^{\mathrm{WAF} 1 / \mathrm{Cip} 1}$ ) promotes cell cycle arrest in response to many stimuli (Abbas and Dutta, 2009). In this study, BaP significantly induced the p21 transcripts in the livers of rare minnow (both males and females). Previous studies have indicated that the increase in p21 mRNA expression was related to p53 functional status, and it was useful for the analysis of p53-mediated cell cycle checkpoints (Wegglarz et al., 2006). Thus, the elevated 


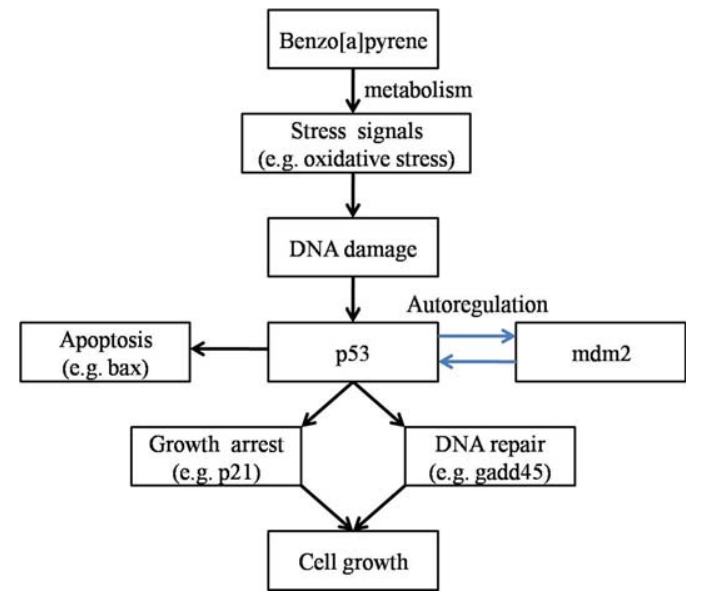

Fig. 4. The program that $\mathrm{p} 53$ responses to BaP perturbation. The figure was according to Shu et al. (2007), and there was minor revision for it. [Color figure can be viewed at wileyonlinelibrary.com]

expression of $p 21$ could indicate a possible role for the p53/ p21 pathway in the cell cycle arrest in rare minnow livers.

The gadd45 family genes have been implicated in stress signaling in response to various physiological or environmental stressors, which results in cell cycle arrest, DNA repair, cell survival and senescence, or apoptosis (Liebermann and Hoffman, 2008). Previous studies have shown that gadd45 family members are rapidly induced by various genotoxic stress agents (Liebermann and Hoffman, 2007; Vairapandi et al., 2002). In this study, the expression of gadd $45 \alpha$ but not gadd $45 \beta$ was induced by BaP in both males and females. Similarly, previous studies have shown that individual members of the gadd 45 family are differentially induced by various genotoxic and environmental stress agents (Shaulian and Karin, 1999; Zhang et al., 1999). Moreover, previous studies have indicated that only gadd $45 \alpha$ is a p53 target gene (Liebermann and Hoffman, 2008). These results and our study on rare minnow suggested that gadd45 members serve similar, but not identical, functions in different stress response pathways (Liebermann and Hoffman, 2008).

Another key gene involved in p53-mediated responses is bax, which is a p53 apoptosis-induced gene (Soares et al., 2012). Bax plays an essential role in the mitochondrial pathway of apoptosis (Donauer et al., 2012); after being released or activated, it undergoes a conformational change and forms an oligomeric pore in the outer mitochondrial membrane through which the apoptosis-stimulating factors (e.g., cytochrome c) are released (Krumschnabel and Podrabsky, 2009). In our study, BaP significantly induced the mRNA expression of bax in rare minnow liver. Similarly, elevated expression of bax was observed in human cell lines exposed to BaP (Jiang et al., 2011). In a previous study, following treatment with p53-activating agents, bax was transcriptionally upregulated together with cyclin $\mathrm{G} 1, m d m 2$ and $p 21$ in zebrafish embryos (Lee et al., 2007), which was consistent with our results on rare minnow. Furthermore, the BaPinduced bax mRNA expression may indicate that apoptosis occurred in the liver of rare minnow, possibly through activation of the intrinsic pathway and related caspases.

IGF play an important role in the etiology of breast cancer (Ren et al., 2004). The IGF binding proteins regulate the action of IGFs, and $>90 \%$ of circulating IGFs are bound to igfbp-3 (Al-Zahrani et al., 2006). Therefore, igfbp-3 functions as a carrier of IGFs in circulation and a mediator of growth suppression in cells. In our study, expression of liver igfbp-3 was not significantly changed in all treatment groups (Fig. 3). Our findings indicated that liver cells did not become cancerous; this could be due to low concentrations of $\mathrm{BaP}$ and a short exposure period. Similarly, tumor cells were not found in light micrographs of hepatic tissues in male and female adult rare minnow (Fig. 1).

\section{CONCLUSIONS}

In summary, we identified and cloned the partial cDNAs of previously unreported p53 network genes, including $p 53$, $p 21$, mdm2, gadd $45 \alpha$, gadd $45 \beta$, igfbp-3, and bax in rare minnow liver. $\mathrm{BaP}$ significantly upregulated these genes, including $p 53, p 21, m d m 2$, gadd $45 \alpha$, and bax. Our findings suggest that rare minnow exposed to $\mathrm{BaP}$ could trigger p53/p21/ gadd $45 \alpha$-mediated cell cycle arrest and DNA repair and p53/bax-mediated apoptosis pathways. Additionally, all these outcomes of the p53 transcriptional program can lead to the suppression of tumors in rare minnow liver. Further studies focusing on combining gene and protein expressions should be performed to identify the mechanism underlying the action of $\mathrm{BaP}$ in fish. Additionally, the p53 network genes in rare minnow could serve as potential molecular biomarkers of environmental carcinogens.

\section{REFERENCES}

Abbas T, Dutta A. 2009. p21 in cancer: Intricate networks and multiple activities. Nat Rev Cancer 9:400-414.

Al-Zahrani A, Sandhu MS, Luben RN, Thompson D, Baynes C, Pooley KA, Luccarini C, Munday H, Perkins B, Smith P, Pharoah PD, Wareham NJ, Easton DF, Ponder BA, Dunning AM. 2006. IGF1 and IGFBP3 tagging polymorphisms are associated with circulating levels of IGF1, IGFBP3 and risk of breast cancer. Hum Mol Genet 15:1-10.

Ananiev J, Tchernev G, Patterson J, Gulubova M, Ganchev G. 2011. P53-"THE GUARDIAN OF GENOME". AMB 38:72.

$\mathrm{Au}$ D. 2004. The application of histo-cytopathological biomarkers in marine pollution monitoring: A review. Mar Pollut Bull 48: 817-834.

Beckerman R, Prives C. 2010. Transcriptional regulation by p53. Cold SH Persp Biol 2.

Blas-Machado U, Taylor HW, Means JC. 2000. Apoptosis, PCNA, and p53 in Fundulus grandis Fish Liver after In Vivo 
Exposure to N-methyl-N'-nitro-N-nitrosoguanidine and 2-Aminofluorene. Toxicol Pathol 28:601-609.

Braithwaite AW, Royds JA, Jackson P. 2005. The p53 story: Layers of complexity. Carcinogenesis 26:1161-1169.

Brzuzan P, Jurczyk L, Luczyński M, Góra M. 2005. Real-time PCR analysis of p53 mRNA levels in tissues of whitefish (Coregonus lavaretus) exposed to benzo [a] Pyrene. Pol J Wet Sci 9:139-143.

Brzuzan P, Woźny M, Ciesielski S, Łuczyński MK, Góra M, Kuźmiński H, Dobosz S. 2009. Microcystin-LR induced apoptosis and mRNA expression of p53 and cdkn1a in liver of whitefish. Toxicon 54:170-183.

Brzuzan P, Woźny M, Góra M, Łuczyński M, Jabłońska A. 2011. Benzo [a] pyrene and cyclopenta [c] phenanthrene suppress expression of p53 in head kidney of rainbow trout. Environ Biotechnol 7:41-45.

Chen S, Hong Y, Scherer SJ, Schartl M. 2001. Lack of ultravioletlight inducibility of the medakafish tumor suppressor gene p53. Gene 264:197-203.

Dabrowska H, Ostaszewska T, Kamaszewski M, Antoniak A, Kopko O, Lang T, Fricke NF, Lehtonen KK. 2012. Histopathological, histomorphometrical, and immunohistochemical biomarkers in flounder from the southern Baltic Sea. Ecotox Environ Safe 78:14-21.

Donauer J, Schreck I, Liebel U, Weiss C. 2012. Role and interaction of p53, BAX and the stress-activated protein kinases $\mathrm{p} 38$ and JNK in benzo (a) pyrene-diolepoxide induced apoptosis in human colon carcinoma cells. Arch Toxicol 86:329-337.

Donehower LA, Harvey M, Slagle BL, McArthur MJ, Montgomery CA Jr, Butel JS, Bradley A. 1992. Mice deficient for p53 are developmentally normal but susceptible to spontaneous tumours. Nature 356:215-221.

Embry MR, Billiard S, Di Giulio R. 2006. Lack of p53 induction in fish cells by model chemotherapeutics. Oncogene 25:20042010.

Feng Z, Zhang H, Levine AJ, Jin S. 2005. The coordinate regulation of the p53 and mTOR pathways in cells. Proc Natl Acad Sci USA 102:8204-8209.

Gottlieb E, Vousden KH. 2010. p53 regulation of metabolic pathways. Cold SH Persp Biol 2.

Hamouchene H, Arlt VM, Giddings I, Phillips DH. 2011. Influence of cell cycle on responses of MCF-7 cells to benzo [a] pyrene. BMC Genome 12:333.

Hassumi-Fukasawa MK, Miranda-Camargo FA, Guimaraes MC, Simoes RT, Donadi EA, Soares CP, Soares EG. 2012. Possible implication of Mdm2 as a prognostic marker in invasive laryngeal carcinoma. Eur Arch Otorhinolaryngol 269:1795-1804.

Hermeking H. 2007. p53 enters the microRNA world. Cancer Cell 12:414-418.

Jiang Y, Zhou X, Chen X, Yang G, Wang Q, Rao K, Xiong W, Yuan J. 2011. Benzo (a) pyrene-induced mitochondrial dysfunction and cell death in p53-null Hep3B cells. Mutation Res Genetic Toxicol Environ Mutagen 726:75-83.

Jones SN, Hancock AR, Vogel H, Donehower LA, Bradley A. 1998. Overexpression of $\mathrm{Mdm} 2$ in mice reveals a p53- independent role for Mdm2 in tumorigenesis. Proc Natl Acad Sci USA 95:15608-15612.

Krause MK, Rhodes LD, Van Beneden RJ. 1997. Cloning of the p53 tumor suppressor gene from the Japanese medaka and evaluation of mutational hotspots in MNNG-exposed fish. Gene 189:101-106.

Krumschnabel G, Podrabsky JE. 2009. Fish as model systems for the study of vertebrate apoptosis. Apoptosis 14:1-21.

Langheinrich U, Hennen E, Stot G, Vacun G. 2002. Zebrafish as a model organism for the identification and characterization of drugs and genes affecting p53 signaling. Curr Biol 12:20232028.

Lee K, Goh W, Xu M, Kua N, Lunny D, Wong J, Coomber D, Vojtesek B, Lane E, Lane D. 2007. Detection of the p53 response in zebrafish embryos using new monoclonal antibodies. Oncogene 27:629-640.

Lesser MP, Farrell JH, Walker CW. 2001. Oxidative stress, DNA damage and 553 expression in the larvae of Atlantic cod (Gadus morhua) exposed to ultraviolet (290-400 nm) radiation. J Exp Biol 204:157-164.

Li W, Zha J, Spear PA, L Z. Yang L, Wang Z, 2009. Changes of thyroid hormone levels and related gene expression in Chinese rare minnow (Gobiocypris rarus) during 3-amino-1, 2, 4triazole exposure and recovery. Aquat Toxicol 92:50-57.

Liebermann DA, Hoffman B. 2007. Gadd45 in the response of hematopoietic cells to genotoxic stress. Blood Cell Mol Dis 39: 329-335.

Liebermann DA, Hoffman B. 2008. Gadd45 in stress signaling. J Mol Signal 3:15-

Liu M, Te C, Zeng F, Sherry JP, Dixon B, Bols NC, Duncker BP. 2011. Characterization of p53 expression in rainbow trout. Comp Biochem Physiol C 154:326-332.

Luft JC, Bengtén E, Clem LW, Miller NW, Wilson MR. 1998. Identification and characterization of the tumor suppressor p53 in channel catfish. Comp Biochem Physiol B 120:675-682.

Mai W, Liu P, Wang W. 2012. Characterization of the tilapia p53 gene and its role in chemical-induced apoptosis. Biotechnol Lett 34:1797-1805.

Momand J, Zambetti GP, Olson DC, George D, Levine AJ. 1992. The mdm2 oncogene product forms a complex with the p53 protein and inhibits p53-mediated transactivation. Cell 69: 1237-1245.

Neel H, Daujat S, Piette J, Thisse C, Thisse B. 2000. The Mdm2 gene of zebrafish: Preferential expression during development of neural and muscular tissues, and absence of tumor formation after overexpression of its cDNA during early embryogenesis. Differentiation 66:61-70.

Olivier M, Hollstein M, Hainaut P. 2010. TP53 mutations in human cancers: Origins, consequences, and clinical use. Cold Spring Harbor Perspect Biol 2.

Pal S, Kokushi E, Cheikyula JO, Koyama J, Uno S. 2011. Histopathological effects and EROD induction in common carp exposed to dietary heavy oil. Ecotoxicol Environ Safe 74:307-314.

Park SY, Lee SM, Ye SK, Yoon SH, Chung MH, Choi J. 2006. Benzo [a] pyrene-induced DNA damage and p53 modulation in 
human hepatoma HepG2 cells for the identification of potential biomarkers for PAH monitoring and risk assessment. Toxicol Lett 167:27-33.

Pei XH, Nakanishi Y, Takayama K, Bai F, Hara N. 1999. Benzo [a] pyrene activates the human p53 gene through induction of nuclear factor $\kappa$ B activity. J Biol Chem 274:35240-35246.

Raver-Shapira N, Marciano E, Meiri E, Spector Y, Rosenfeld N, Moskovits N, Bentwich Z, Oren M. 2007. Transcriptional activation of miR-34a contributes to p53-mediated apoptosis. Mol Cell 26:731-743.

Ray SS, Swanson HI. 2004. Dioxin-induced immortalization of normal human keratinocytes and silencing of p53 and p16INK4a. J Biol Chem 279:27187-27193.

Ren Z, Cai Q, Shu XO, Cai H, Li C, Yu H, Gao YT, Zheng W. 2004. Genetic polymorphisms in the IGFBP3 gene: Association with breast cancer risk and blood IGFBP-3 protein levels among Chinese women. Cancer Epidemiol Biomarkers 13:1290-1295.

Ruiz P, Orbea A, Rotchell JM, Cajaraville MP. 2012. Transcriptional responses of cancer-related genes in turbot Scophthalmus maximus and mussels Mytilus edulis exposed to heavy fuel oil no. 6 and styrene. Ecotoxicol 3:820-831.

Schmittgen TD, Livak KJ. 2008. Analyzing real-time PCR data by the comparative CT method. Nat Protoc 3:1101-1108.

Shaulian E, Karin M. 1999. Stress-induced JNK activation is independent of gadd45 induction. J Biol Chem 274:29595-29598.

Shu KX, Li B, Wu L-X. 2007. The p53 network: p53 and its downstream genes. Colloid Surf B 55:10-18.

Soares J, Castro LF, Reis-Henriques MA, Monteiro NM, Santos MM. 2012. Zebrafish (Danio rerio) life-cycle exposure to chronic low doses of ethinylestradiol modulates p53 gene transcription within the gonads, but not NER pathways. Ecotoxicol 21:1513-1522.

Storer NY, Zon LI. 2010. Zebrafish models of p53 functions. Cold Spring Harbor Perspect Biol 2.

Thompson ED, Burwinkel KE, Chava AK, Notch EG, Mayer GD. 2010. Activity of Phase I and Phase II enzymes of the benzo [a] pyrene transformation pathway in zebrafish (Danio rerio) following waterborne exposure to arsenite. Comp Biochem Physiol C 152:371-378.
Vairapandi M, Balliet AG, Hoffman B, Liebermann DA. 2002. gadd $45 \mathrm{~b}$ and gadd $45 \mathrm{~g}$ are $\mathrm{cdc} 2 /$ cyclinB1 kinase inhibitors with a role in $\mathrm{S}$ and $\mathrm{G} 2 / \mathrm{M}$ cell cycle checkpoints induced by genotoxic stress. J Cell Physiol 192:327-338.

Verhofstad N, Pennings J, van Oostrom C, van Benthem J, van Schooten F, van Steeg H, Godschalk R. 2010. Benzo (a) pyrene induces similar gene expression changes in testis of DNA repair proficient and deficient mice. BMC Genomics 11:333.

Vilborg A, Wilhelm MT, Wiman KG. 2010. Regulation of tumor suppressor p53 at the RNA level. J Mol Med 88:645-652.

Vousden KH, Prives C. 2009. Blinded by the light: The growing complexity of p53. Cell 137:413-431.

Weeglarz L, Molin I, Orchel A, Parfiniewicz B, Dzierżewicz Z. 2006. Quantitative analysis of the level of p53 and p21WAF1 mRNA in human colon cancer HT-29 cells treated with inositol hexaphosphate. Acta Biochim Pol 53:349-356.

Wills LP, Jung D, Koehrn K, Zhu S, Willett KL, Hinton DE, Di Giulio RT. 2010. Comparative chronic liver toxicity of benzo[a]pyrene in two populations of the atlantic killifish (Fundulus heteroclitus) with different exposure histories. Environ Health Perspect 118:1376-1381.

Wolf JC, Dietrich DR, Friederich U, Caunter J, Brown AR. 2004. Qualitative and quantitative histomorphologic assessment of fathead minnow (Pimephales promelas) gonads as an endpoint for evaluating endocrine-active compounds: A pilot methodology study. Toxicol Pathol 32:600-612.

Yang L, Zha J, Li W, Li Z, Wang Z. 2010. Atrazine affects kidney and adrenal hormones (AHs) related genes expressions of rare minnow (Gobiocypris rarus). Aquat Toxicol 97:204-211.

Zha J, Wang Z, Wang N, Ingersoll C. 2007. Histological alternation and vitellogenin induction in adult rare minnow after exposure to ethynylestradiol and nonylphenol. Chemosphere 66: 488-495.

Zhang W, Bae I, Krishnaraju K, Azam N, Fan W, Smith K, Hoffman B, Liebermann DA. 1999. CR6: A third member in the MyD118 and Gadd45 gene family which functions in negative growth control. Oncogene 18:4899-4907.

Zhao T, Xu Y. 2010. p53 and stem cells: New developments and new concerns. Trends Cell Biol 20:170-175. 